https://jurnal.uns.ac.id/jdc

\title{
Analisis Nilai Kemanusiaan dalam Kepedulian Siswa Sekolah Dasar pada Daerah Berpotensi Bencana Gunung Merapi Di Kabupaten Magelang
}

\author{
Rasidi, Galih Istiningsih \\ Universitas Muhammadiyah Magelang \\ rasidi@ummgl.ac.id
}

\section{Sejarah Artikel}

diterima 7/04/2020

disetujui 6/07/2020

diterbitkan 1/08/2020

\begin{abstract}
The purpose of this study is to describe: 1) the human values of students; 2) student care; 3) priority analysis for aspects of increasing student awareness. Quantitative research, by type of survey research. The population is grade 5 elementary school students in Srumbung subdistrict, Magelang district with a total of 505 in 29 elementary schools. The sample used was purposive sampling, with a sample of 5 schools, the subject was class $V$ students with a total of 110 students. The instrument uses a questionnaire as its main instrument. Analysis of the data is descriptive percentages at an early stage, followed by regression analysis to obtain proportions as a priority for increasing disaster awareness. The results showed; 1) student awareness in human values is $78.64 \%$ with a good category. 2) disaster social awareness of $77.89 \%$ with a good category. 3) The results of the regression analysis to see the relative contribution obtained by the main indicators; a) help others (55\%). b) escape (18\%). c) surrender to God (18\%). d) evacuation efforts (9\%). The results of the regression analysis of each aspect obtained by mapping for priorities that need to be improved in succession are: surrender to God, efforts to evacuate, maintain relationships, provide food, protect the environment, help evacuate.
\end{abstract}

Keywords: awareness, disaster, human values

\section{Abstrak}

Tujuan penelitian ini adalah mendeskripsikan: 1) nilai kemanusiaan siswa; 2) kepedulian siswa; 3) analisis prioritas untuk aspek peningkatan kepedulian siswa. Penelitian kuantitatif, dengan jenis penelitian survei. Populasinya, siswa SD kelas V di Kecamatan Srumbung, Kabupaten Magelang dengan jumlah 505 di 29 SD. Sampel yang digunakan adalah purposive Sampling, dengan jumlah sampel 5 sekolah, subjeknya adalah siswa kelas $V$ dengan jumlah 110 siswa. Instrumen menggunakan angket sebagai instrumen utamanya. Analisis datanya adalah deskriptif persentase pada tahap awal, dilanjutkan dengan analisis regresi untuk memperoleh proporsi sebagai prioritas untuk peningkatan kepedulian bencana. Hasil penelitian menunjukkan; 1) kesadaran siswa dalam nilai kemanusiaan sebesar $78,64 \%$ dengan kategori baik. 2) kepedulian sosial bencana sebesar $77,89 \%$ dengan kategori baik. 3) Hasil analisis regresi untuk melihat sumbangan relatif diperoleh indikator utama; a) membantu orang lain $(55 \%)$. b) penyelamatan diri (18\%). c) pasrah pada tuhan (18\%). d) upaya mengungsi $(9 \%)$. Hasil analisis regresi tiap aspek yang diperoleh pemetaan untuk prioritas yang perlu ditingkatkan berturut-turut adalah: pasrah dengan tuhan, upaya mengungsi, menjaga hubungan, memberi makanan, menjaga lingkungan, membantu mengungsi.

Kata kunci: kepedulian, bencana, nilai kemanusiaan 


\section{PENDAHULUAN}

Indonesia merupakan Kawasan rentan dengan bencana erupsi gunung berapi dengan ancaman bahaya dan kerugian. berdampak pada kerugian. Merapi yang berdampak pada Gunung Merapi berada di propinsi D.I. Yogyakarta dan Jawa Tengah. Meletusnya gunung ini merupakan bencana yang mengakibatkan konsekuensi kompleks. Permukaan tanah pada lahan area erupsi vulkanik pada umumnya tertutupi oleh lava, aliran piroklastik dan juga tepra (debu vulkanik) dan lahar. Deposit lahar biasanya sangat beragam ketebalan tutupannya terhadap permukaan tanah, bahan sering terdapat spotspot yang tidak tertutupi lahar sehingga menyisakan vegetasi insitu. Iklim yang lebih hangat dan sebaran hujan yang lebih teratur akan membantu proses pembentukan tanah dari material erupsi dan dan membantu recovery lahan yang terkena dampak erupsi. Klasifikasi bahaya Erupsi gunung Merapi memiliki bahaya primer dan sekunder dan dapat merusak lahan. (Rahayu et al., 2014)

Erupsi besar terakhir terjadi pada tahun 2010. Letusan tahun 2010 menyebabkan 2.682 rumah rusak berat di DIY dan 174 rumah rusak berat di Jawa Tengah (Maarif \& Pramono, 2008) Secara umum Kerusakan yang diakibatkan oleh erupsi Gunung Merapi berdampak pada sektor permukiman, infrastruktur, sosial, ekonomi, dan lintas sektor yang mengakibatkan terganggunya aktivitas dan pelayanan umum di daerah sekitarnya (Fathurrohman. P \& Sutikno., 2007)

Kerugian bencana yang begitu besar menuntut bentuk penanganan korban bencana merapi perlu ditata secara komprehensif. Namun, masyarakat di Indonesia belum memiliki kesadaran dan kesiapan untuk menghadapi bencana yang mengakibatkan banyaknya kerugian. Hal ini ditunjukan selama tahun 2018 Update sampai dengan 26-05-2018 terjadi 1,134 kejadian bencana, Korban (Jiwa): 124 Meninggal \& Hilang, 427 Luka-luka, 777,620 Terdampak \& Mengungsi. Rumah rusak (UNIT): 2,700 Rusak Berat, 4,760 Rusak Sedang, 12,672 Rusak Ringan. Fasilitas (UNIT): 32 Fasilitas Kesehatan, 242 Fasilitas Peribadatan, 252 Fasilitas Pendidikan. (BNPB, 2018). Kerugian tersebut berimplikasi pada evolusi pada penanganan korban bencana.

Pergeseran paradigma tanggap bencana ke mitigasi bencana, Paradigma penanggulangan bencana berkembang ke pandangan yang lebih progressif yang melihat bahwa bencana sebagai bagian dari pembangunan dan bencana adalah masalah yang tidak berhenti. Oleh karena itu penanggulangan bencana tidak dapat dilepaskan dari masalah pembangungan sehingga upaya yang dilakukan adalah mengintegrasikan program pembangunan dengan penanggulangan bencana. Pandangan yang lebih progresif yang berkembang juga dipengaruhi ilmu pengetahuan alam dan sosial. Berkembangnya pengetahuan mendorong timbulnya pandangan bahwa bencana adalah merupakan proses geofisik, geologi dan hidrometeorologi yang dapat mempengaruhi lingkungan fisik dan membahayakan kehidupan manusia. (Pemerintah Indonesia, 2008). 
Kajian literatur tentang pengetahuan resiko bencana (Mamon et al., 2017)yang hasilnya menunjukkan persentase tinggi siswa yang memahami beberapa konsep dan ide yang terkait dengan bencana. Selain itu, siswa Kelas 11 siap beradaptasi dan sadar risiko yang ditimbulkan oleh bencana. Namun, siswa ditemukan memiliki persepsi rendah terhadap risiko bencana. Penelitian ini memungkinan adanya kurikulum kebencanaan dalam pembelajaran di sekolah. Ini memungkinkan pihak sekolah baik guru dan kepala sekolah untuk meningkatkann kemampuan adaptasi dan kesadaran bencana melalui program sekolah dan proses pembelajaran.

Laporan data manajemen bencana dari International Space University Strasbourg Central Campus Disaster Management: Space based solutions for developing nations,(Bruce et al., 2018) 1) rekomendasi menunjukkan perlunya pengembangan informasi dan teknologi untuk akses kebencanaan. 2) Pemanfaatan satelit untuk komunikasi dan penggunaan daerah daerah prioritas bencana.3) Perlu pengembangan aplikasi dengan pencermatan ekologi dan lingkungan di daerah rawan bencana. 4) Pengukuran elektromagnetik untuk deteksi dini bencana. Perlu monitoring deteksi tektonik. Laporan ini masih berfokus pada penyiapan secara sistem dan infrastruktur belum menyentuh pada sumber daya manusia yang menjalankannya. Pengembangan saluran informasi bisa dikembangkan di lembaga-lembaga pemerintah atau swasta. Ini bisa dikembangkan di sekolah, sebagai lembaga pendidikan yang paling rentan untuk mengalami kerugian.
Penelitian berikutnya (Rasidi et al., 2017) Hasil penelitian tersebut menunjukan bahwa kondisi guru dan kepala sekolah memiliki leadership yang kondisinya cukup baik dan perlu peningkatan. Proses peningkatan kepemimpinan guru dalam pembelajaran pada dasarnya dilakukan untuk pengembangan potensi siswa sehingga siswa mampu meningkatkan

kesadaran bencananya. Penelitian masih bersifat permukaan hanya melihat persepsi guru tentang kepemimpinan yang dilakukan di sekolah. Belum ada bagian yang mengkaji empiris yang mengungkap kemampuan guru pengurangan resiko bencana khususnya dalam pembelajaran.

Ketika terjadi bencana, sistem sosial, koneksi dan komunikasi antara elemen terganggu. Unit sosialnya (komunitas, kelompok sosial, dan individu), mengakibatkan terganggunya fisik dan psikologis. Dengan demikian, perlu tindakan penanggulangan luar biasa atau darurat untuk membangun kembali stabilitas (Adila et al., 2017). Dasar ini yang menuntut perlunya pendekatan psikologis dalam penanganan bencana. Kondisi bencana yang terjadi mengarahkan pada kondisi psikologis salah satunya Nilai kemanusiaan sendiri maksudnya adalah nilai yang dijalankan dengan penuh kesadaran secara pemikiran, sikap, dan perilaku dalam menegakan penghormatan terhadap hak - hak asasi manusia dan kemuliaanya yang sesuai terhadap nilai - nilai akidah dan moral yang berlaku pada masyarakat. Kondisi ini perlu diperkuat untuk memperoleh persepsi yang kuat oleh tindakan nyata dalam bentuk kepedulian siswa. Nilai kemanusiaan menjadi fokus karena hal ini 
merupakan bagian yang bisa meningkatkan kondisi ketika terjadi bencna dimana seornag bisa saling membantu. Kondisi kemanusiaan yang baik akan meningkatkan solidaritas masyarakat dalam mengatasi kondisi bencana sehingga bisa mengatasi kondisi Bersamasama dengan baik dan bangkit Bersama-sama melakukan tindkaan nyata perbaikan.

Tindakan nyata yang merupakan bagian penting adalah kepedulian satu orang untuk melakukan kontribusi untuk perbaikan pada korban bencana. kepedulian dipicu dari kesadaran antar pribadi serta nilai, pemikiran yang dimilikinya. Kepedulian bencana oleh masyarakat perlu dilakukan dengan tujuan mengarahkan pada handarbeni dan kebersamaan. Hal ini perlu dilakukan serta perlu diungkap dalam dunia Pendidikan naik secara formal, nonformal, maupun informal.

Sekolah sebagai entitas masyarakat perlu mengajarkan kepedulian sesame, hal ini akan sangat berarti ketika terjadi kodisi gawat darurat. Orang yang memiliki kepedulian dalam kondisi ini, akan melakuakn sesuatu yang bermanfaat bagi orang banyak, bukan hanya memikirkan keselamatan diri melainkan keselmatan ornag banyak, setiap tindkana yang dilakukannnya berorientasi pada kepentingan orang banyak. Pembelajaran serta penanaman karakter di sekolah perlu dievaluasi dan diungkap tentang apa yang diajarkan sesuai dnegan kebutuhan atau tidak.

Urgensi penelitian mitigasi dalam praktisnya mengungkap fenomena kesadaran bencana dalam proses pembelajaran untuk pengurangan resiko bencana di sekolah. Kemampuan guru dan proses pembelajaran bisa menjadi bahan diskusi untuk pengambilan kebijakan sekolah dalam program sekolah dan program pembelajaran. Kemampuan guru yang diungkap dan digunakan untuk perbaikan program mirigasi di sekolah dan masyarakat. Upaya yang skalanya lebih besar menjadi perpanjangan tangan dari pelaksanaan program pemerintah, BNPB, Pemerintah Daerah, lembaga swasta, dan lembaga swadaya masyarakat yang berkepentingan dalam pengurangan resiko bencana. Konsep tersebut bisa dijadikan dasar untuk pengembangan pendidikan layanan khusus di daerah berpotensi bencana. Permasalahan dalam penelitian ini adalah bagaimana kesadaran siswa dalam upaya pengurangan rencana bencana di SD di daerah berpotensi bencana di Kabupaten Magelang.

Berpijak pada pentingnya penelitian mitigasi bencana, prioritas kepedulian serta nilai kemanusiaan, maka perlu diungkap secara empiris tentang pemikiran siswa dalam kepedulian bencana. penelitian ini akan mengungkap data secara deskriptif dan mencari rekomendasi solutif untuk peningkatan kepedulian siswa di daerah bencana. hal ini didukung oleh Muhammadiyah, ucapan terima kasih kami sampaikan pada Diktilitbang Muhammadiyah yang telah membiayai penelitian ini. Tujuan penelitian ini adalah: 1) mengungkap secara deskriptif tentang nilai kemanusiaan siswa; 2) deskripsi kepedulian bencana siswa; 3) analisis prioritas aspek untuk peningkatan kepedulian siswa di sekolah. 
Kejadian bencana menimbulkan beberapa masalah sulit, seperti nilai kehidupan manusia, tetapi dapat digunakan untuk mendukung segala aspek pengambilan keputusan tidak hanya evakuasi, seperti perencanaan penggunaan lahan dan pembentukan kemampuan pemantauan(Susan et al., 2015). Perlu pengkajian secara empirik tentang nilai kemanusiaan dalam situasin bencana. Penelitian ini bersifat kuantitatif, yang termasuk dalam penelitian survei. Penelitian ini menilai satu variabel yaitu nilai kemanusiaan dlaam kesadaran bencana. sub variabel yang diteliti adalah 1) kesadaran membantu orang lain, 2) kesadaran akan penyelamatan diri, 3) kesadaran dalam upaya mengungsi dan 4) kesadaran dalam upaya mengungsi. Sedangkan variabel terikatnya adalah kepedulian siswa yang meliputi tindakan siswa dalam 1) membantu mengungsi, 2) menjaga hubungan baik, 3) menjaga lingkungan. Setting penelitian dilakukan di kecamatan srumbung yang merupakan salah satu kecamatan yang masuk dalam sekolah berpotensi di Kabupaten Magelang. Waktu penelitian dilakukan pada waktu oktober 2019 sampai januari 2020. Populasinya adalah siswa SD di kecamatan srumbung dengan jumlah populasi adalah kelas $\mathrm{V}$ dengan jumlah $505 \mathrm{di}$ 29 SD. Sampel penelitian 110 siswa SD. Sampel yang digunakan adalah purposive Sampling, dengan jumlah sampesl 5 sekolah. instrument yang digunakan adalah angket, analisis yang digunakan adalah deskriptif persentase dan analisis regresi.

\section{PEMBAHASAN}

Berdasarkan perhitungan statistik terhadap data nilai kemanusiaan dalam kesadaran bencana siswa di SD di Kabupaten Magelang dapat dideskripsikan yaitu nilai tertinggi;16, nilai terendah; 7 , nilai rata - rata; 12.58 , modus; 12 , median; 12, st. deviasi; 2.09, jumlah; 1384, jumlah maksimal; 1760, persentase sebesar $78.64 \%$

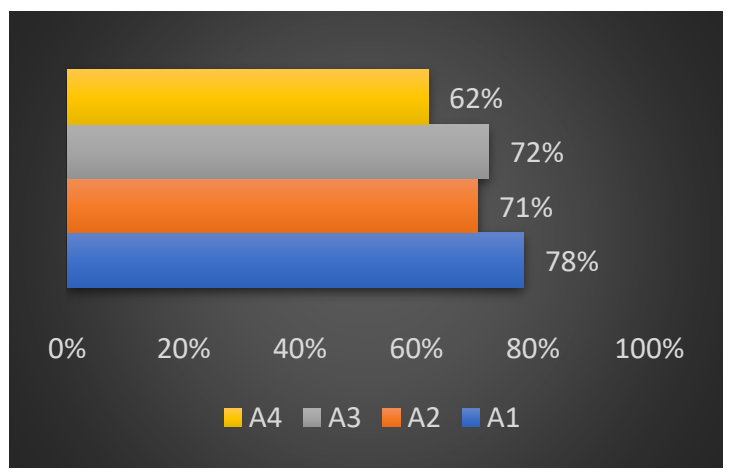

Gambar 1

Persentase Nilai Kemanusiaan

A1: membantu orang lain

A2: penyelamatan diri

A3: upaya mengungsi

A4: pasrah dengan tuhan

Kesadaran dalam nilai kemanusiaan diperoleh skor 1.384 dan diperoleh persentase sebesar 78,64\%. Deskripsi aspek pertama $78 \%$, aspek kedua $71 \%$, aspek ketiga $72 \%$, aspek keempat $62 \%$. 


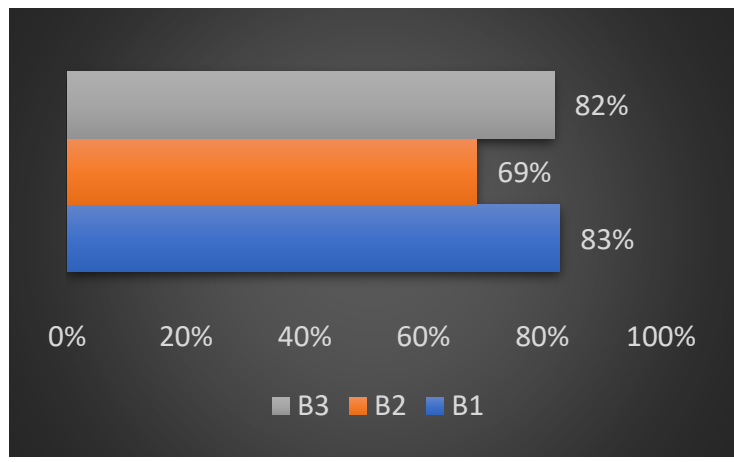

Gambar 2.

B1: Membantu mengungsi

Persentase Kepedulian bencana Siswa

B2: Menjaga hubungan baik

B3: Menjaga lingkungan

Kepedulian siswa secara keseluruhan memperoleh skor 1029 dan kemudian dibandingkan skor total sehingga diperoleh persentase $77.89 \%$. aspek pertama diperoleh persentase $82 \%$, aspek kedua diperoelh persentase $69 \%$, aspek ketiga diperoleh persentase $83 \%$.

Analisis variabel antar sub variabel nilai kemanusiaan terhadap variabel kepedulian siswa diperoleh tabel berikut.

Tabel 1

Hasil uji regresi antar sub variabel

Correlations

\begin{tabular}{|c|c|c|c|c|c|c|c|c|}
\hline & $\mathrm{A} 1$ & A2 & A3 & A4 & B1 & B2 & B3 & B4 \\
\hline$\overline{A 1}$ & t & & $.622^{\star *}$ & $.479^{\star *}$ & $.200^{*}$ & $.308^{* *}$ & $.242^{*}$ & $.282^{* *}$ \\
\hline$A 2$ & & & $.274^{* *}$ & & & & & \\
\hline A3 & & & 1 & $.344^{* *}$ & $.270^{* *}$ & & & \\
\hline A4 & & & & 1 & $489^{* *}$ & & $274^{\star \star}$ & \\
\hline
\end{tabular}

Persentase hubungan antar aspek yang menyusun variabel nilai kemanusiaan, komposisi sumbangsihnya sebagai berikut.

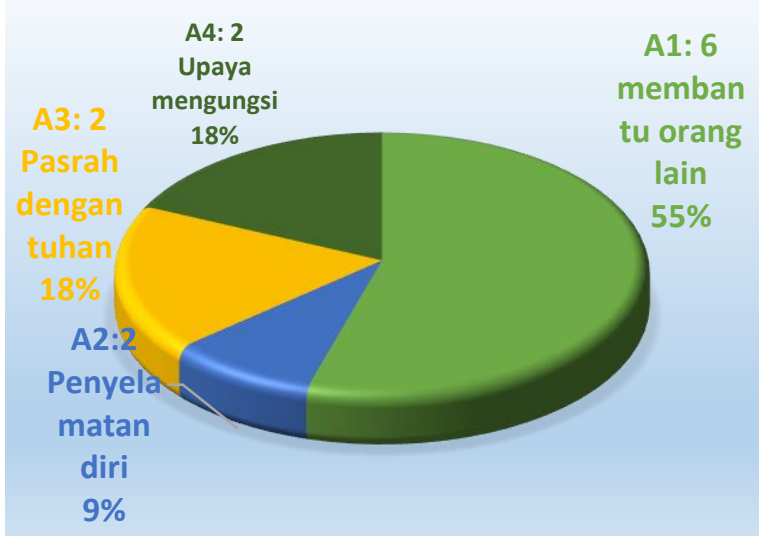

Gambar 3. Susunan kepedulian siswa ditinjau dari nilai kemanusiaan

Aspek yang paling rendah kondisi bencana dan pasrah dengan dalam aspek ini yaitu terbiasa dengan hidup mati. Pada item ini diperoleh 
persentase sebesar 62\%. Melalui wawancara dan observasi. Pihak yang mendukung kondisi terbiasa di tempat bencana, dan kepasrahan tentang hidup dan mati adalah pengenalan dan pemahaman yang dilakukan oleh orang tua/orang terdekat. Cara dukungan yang diperoleh siswa diidentifikasi menjadi

Prioritas peningakatan kesadaran bencana melalui upaya kesadaran nilai kemanusiaan. Ada empat prioritas yang perlu diperhatikan dalam meningkatkan kesadaran bencana yaitu.

Prioritas pertama difokuskan pada sikap dalam membantu orang lain. Upaya membantu ini perlu lebih fokus pada upaya kepasrahan seseorang pada tuhan, upaya mengungsi, menjaga hubungan kemanuisaan, kesediaan memberi makanan, menjaga lingkungan, membantu mengungsi.

Kepedulian bencana yang dimiliki siswa yang perlu ditingkatkan adalah kesadaran dalam membantu orang lain, kesadaran dalam penyelamatan diri, kesadaran pasrah pada tuhan, dan kesadaran dalam upaya mengungsi. Prioritas kesadaran bencana dalam membantu orang lain diarahkan pada membantu orang lain yang motivasinya diarahkan pada pasrah dengan tuhan. Membantu orang lain merupakan bagian dari posisi seseorang sebagai makhluk tuhan. Tindakan membantu orang lain yang dilakuakn siswa

Motivasi untuk membantu orang lain diarahkan pada hubungan dengan tuhan serta upaya yang dilakukan sesuai hasil yang diinginkan. Tindakan membantu orang lain diorientasikan pada konsep hubungan baik dengan orang lain. Mampu berbagi makanan dan logistik
2 bentuk yaitu: mendukung material, mendukung.

Koneksi antar komponen kesadaran bencana, menjadi bagian penting dalam menentukan prioritas untuk penguatan kesadaran bencana pada siswa. Interkoneksi dalam komponen nilai kemanusiaan.

adalah mengarahkan untuk membantu orang lain dalam mengungsi. Guru mengarahkan siswa untuk menjaga hubungan baik dengan siapapaun. Membantu orang lain wujud yang bisa dilakukan dengan memberi makanan dan logistik ketika situasi bencana terjadi. Siswa bisa bertindak dalam menjaga lingkungan. Siswa selain itu juga perlu diajari tindkaan yang dilakukan untuk membantu orang lain

Konteks dalam pendidikan, siswa perlu diarahkan untuk bisa membantu orang lain yang perlu diajarkan oleh orang dewasa. Konsep yang bisa diterapkan dalam mengarahkan siswa untuk sadar membantu orang lain (WebsterStratton \& Reid, 2004): 1)Mempelajari apa arti persahabatan dan bagaimana bersikap ramah. 2)Memahami cara untuk membantu orang lain. 3)Mempelajari konsep berbagi dan hubungan. 4)Berbagi dan membantu. 5)Mempelajari apa arti kerja tim. 6)Memahami manfaat berbagi, membantu, dan kerja tim. 7)Mempraktikkan keterampilan persahabatan.

ketika terjadi situasi bencana.Hal ini dilakukan untuk menjaga lingkungan sekitar baik dengan menjaga lingkungan fisik, maupun upaya preventif dalam mendesain bangunan yang digunakan.

Siswa sebagai manusia yang akan dewasa harus siap dengan kondisi bencana. Kondisi darurat 
(emergency) yang sangat gawat, bukan hanya menyelamatkan nyawa korban, tetapi juga mempertaruhkan hidup para relawan. Suasana yang mencekam di area bencana merupakan area perjuangan baik bagi para relawan maupun para korban untuk berjauang tetap hidup atau mati.(Paidi, 2012). Kondisi ini perlu dimengerti dan disosialisasikan pada siswa sejak dini sehingga ketika terjadi kondisi gawat darurat siswa mampu bertindak dengan tepat.

Hasil analisis menunjukan bahwa kepasarahan pada tuhan akan memberikan sumbanganbterhadap kondisi kerugian bencana secara psikologis. Sikap pasrah menerima keadaan ini ternyata menjadi sumber kekuatan individu sehingga pada umumnya mereka sudah bisa melupakan peristiwa bencana tersebut tanpa mengalami stres berkepanjangan (Prihatin, 2018). Siswa perlu diarahkan untuk memiliki kepasrahan ini, dengan cara mendekatkan diri pada tuhan dengan ibadah baik kepada tuhan maupun ibadah kepada sesame manusia.

sejumlah besar korban juga terpaksa mengungsi akibat bencanabencana semacam ini atau akibat munculnya rasa khawatir terhadap kerusakan-kerusakan yang mungkin terjadi lagi di masa depan.(IASC, 2006). Kondisi pengungsisan ketika terjadi bencana perlu dimengerti siswa sehingga saat terjadi pengungsian siswa mampu untuk bersikap positif dan bertindak konstruktif sehingga bukan sebagai korban saja, melainkan ikut berkontribusi dalam kondisi pengungsian yang membangun. Siswa di Sekolah Dasar perlu dikenalkan sejak dini melalui pendidikan mitigasi bencana sehingga kesiapan siswa menghadapi bencana dalam kondisi optimal. Perlu integrasi Pendidikan siswa dengan tingkat kesadaran diri dan lingkungan sehingga budaya saling tolong menolong, dan kebersaman terbangun. Hal ini sesuai dengan hasil riset tentang tantangan nyata strategi pendidikan adalah membangun budaya kesadaran dan pencegahan bencana, dengan memberdayakan masyarakat untuk beradaptasi dengan kondisi geologis yang dinamis (Karnawati \& Pramumijoyo, 2005). Perlu adanya sinergi antara kepedulian sosial dianatara warga di daerah berpotensi bencana. Kepedulian tidak hanya pada sebatas manusia, melainkan pada mahkluk, vegetasi, hewan dan tumbuhan yang hidup di lereng Merapi. Di daerah berpotensi bencana gunung merapi telah dijalin kemitraan dengan masyarakat untuk ikut membangun dan menjaga hutan Merapi. Strategi penting bagi otoritas Taman Nasional Gunung Merapi adalah dengan memposisikan masyarakat dusun dan norma-norma mereka sebagai penerima manfaat dan mitra dalam mengelola taman nasional, yang menyoroti bahwa keberadaan mereka tidak boleh diabaikan (Umaya et al., 2020).

Hasil penelitian ini, masih dangkal dan hanya meneliti kondisi persepsi siswa akan nilai kemanusiaan dan kepedulian siswa. Peneliti selanjutnya bisa meneliti kondisi yang lebih nyata fokus pada peningkatan kepedulian siswa bisa melalui penelitian Tindakan, eksperimen dan pengembangan. Rekomendasi penelitian yang bisa dilakukan selanjutnya adalah, 1) Penelitian tindakan yang bisa dilakukan adalah penelitian kesiapsiagaaan atau kesadaran bencana siswa, dengan integrasi Pendidikan mitgasi bencana 
pada pembelajaran. 2) Penelitian eksperimen, bisa menguji model, metode atau menguji metode yang cocok dan tepat dalam mengembangkan kesiapsiagaan atau kesadaran siswa dalam kondisi bencana. 3) penelitian pengembangan bisa mengembangkan sebuah produk pembelajaran, baik model, bahan ajar, media yang bisa divalidasi dan dikembangkan khusus didaerah bencana Merapi sehingga memperkuat tujuan dan sasaran Pendidikan layanan khusus.

\section{SIMPULAN}

Hasil penelitian menunjukkan bahwa 1) Kesadaran siswa dalam nilai kemanusiaan sebesar $78,64 \%$ dengan kategori baik. 2) Kepedulian sosial bencana sebesar $77,89 \%$ dengan kategori baik. 3) Hasil analisis regresi untuk melihat sumbangan relatif diperoleh indikator utama; a) membantu orang lain (55\%). b) penyelamatan diri (18\%). c) pasrah pada tuhan (18\%). d) upaya mengungsi $(9 \%)$. Hasil analisis regresi tiap aspek yang diperoleh pemetaan untuk prioritas yang perlu ditingkatkan berturut-turut adalah membantu orang lain, membantu mengungsi, pasrah dengan tuhan dan penyelematan diri. Hal ini berimplikasi pada guru yang perlu menekankan hal tersebut dalam pembelajaran, orang tua perlu mendidik anak dengan kepedulian, serta masyarakat perlu membangun tatanan masyarakat yang kuat untuk meningkatkan kepedulian sosial. Hal ini dilakukan untuk memperkuat mental dan mengurangi korban serta kerugian bencana. Upaya dan tindakan positif perlu diusung bersama antara guru, siswa dan masyarakat sehingga strategi pengurangan resiko bencana bisa terwujud.

\section{DAFTAR PUSTAKA}

Adila, I., Dewi, W. W. A., Tamitiadini, D., \& Syauki, W. R. (2017). Disaster mitigation action plan: Digital media on improving accountability and community relationships. 0-9.

BNPB, D. P. (2018). Penilaian Indeks Ketahanan Daerah (lkd) Dan Indeks Risiko Bencana Indonesia (Irbi). Direktorat PRB, BNPB.

Bruce, D., Connolly, J., Cowley, P. B., Davis, M., Nikoloff, P., Peeters, P. W., Bessat, S., Butler, A., Herrmann, J., Karacalioglu, G., Liew, A., Schneider, S., Agutter, W., Blake, D., Cairns, P. I., Chia, L. W., Cook, M., Systems, N., Law, I. A., ... Reynolds, C. G.
(2018). Disaster management: space Based solutions for developing nations. University of south Australia.

Fathurrohman. P \& Sutikno. (2007). Strategi Belajar Mengajar. 55. https://doi.org/10.1017/CBO9781 107415324.004

IASC. (2006). Melindungi Para Korban Bencana Alam: Panduan Operasional IASC (Komite Tetap Antar-Lembaga) tentang Hak-hak Asasi Manusia (HAM) dan Bencana-bencana Alam (terjemahan). Diterbitkan oleh: Brookings-Bern Project on Internal Displacement.

Karnawati, D., \& Pramumijoyo, S. 
(2005). Strategy for Promoting Education for Natural Disaster Reduction in Indonesia and ASEAN Region.

Maarif, S., \& Pramono, R. (2008). Maryani , Enok . Model Pembelajaran Mitigasi Bencana Dalam Ilmu Pengetahuan Sosial Di Sekolah Menengah Pertama *) Rilus A . Kinseng , Euis Sunarti Kontestasi Pengetahuan Dan Pemaknaan Tentang Ancaman Bencana Alam ( Studi Kasus Ancaman Bencana Gunung Merap.

Mamon, M. A. C., Suba, R. A. V., \& Son Jr, I. L. (2017). Disaster Risk Reduction Knowledge of Grade 11 Students: Impact of Senior High School Disaster Education in the Philippines. International Journal of Health System and Disaster Management, 5(3), 6974.

https://doi.org/10.4103/ijhsdm.ijhs $\mathrm{dm}$

Paidi. (2012).

Pengelolaan manajemen risiko bencana alam di indonesia. Jurnal Manajemen STIE Dharma Bumiputera, 29(83).

Pemerintah Indonesia. (2008). Peraturan Pemerintah Republik Indonesia Nomor 21 Tahun 2008 Tentang Penyelenggaraan Penanggulangan Bencana Dengan Rahmat Tuhan Yang Maha Esa Presiden Republik Indonesia, (Vol. 85, Issue 1, pp. 2071-2079). Sekretariat Negara. https://doi.org/10.1016/j.bbapap.2 013.06.007

Prihatin, R. B. (2018). Masyarakat Sadar Bencana: Pembelajaran Dari Karo, Banjarnegara, Dan Jepang. Jurnal Aspirasi, 9(2), 221-239.

Rahayu, Ariyanto, D. P., Komariah,
Hartati, S., Syamsiyah, J., \& Dewi, W. S. (2014). Dampak Erupsi Gunung Merapi Terhadap Lahan Dan Upaya-Upaya Pemulihannya. Caraka Tani Jurnal IImu-IImu Pertanian, XXIX(1), 61-72. Dampak Erupsi Gunung Merapi Terhadap Lahan Dan Upaya-Upaya Pemulihannya (Effects of Merapi Mountain Eruption on Arable Land and the Efforts of Rehabilitation)

Rasidi, Istiningsih, G., \& Purwandari, S. (2017). Kompetensi kepala sekolah dalam instructional leadership sd negeri berpotensi bencana di kabupaten magelang. Holistika Jurnal IImiah PGSD, 1(1), 46-56.

Susan, C. L., Sparks, S., Brown, S. K., Jenkins, S. F., \& Vye-Brown, C. (2015). Global Volcanic Hazarss And Risk (Issue December). University Printing House.

Umaya, R., Hardjanto, Soekmadi, R., \& Sunito, S. (2020). Direct economic benefits and human dependence toward gunung Merapi National Park, Indonesia. Biodiversitas, 21(3), 982-993. https://doi.org/10.13057/biodiv/d2 10318

Webster-Stratton, C., \& Reid, M. J. (2004). Strengthening Social and Emotional Competence in Young Children-The Foundation for Early School Readiness and Success. Infants \& Young Children, 17(2), 96-113. https://doi.org/10.1097/00001163200404000-00002 